\title{
Optimization of the procedure for extracting nucleic acids from aloe
}

\author{
J. Li ${ }^{1}$, Y.S. Zhang ${ }^{1}$, C.M. Liao ${ }^{2}$ and X.H. Liu ${ }^{1}$ \\ ${ }^{1}$ College of Life Science, China West Normal University, Nanchong City, \\ China \\ ${ }^{2}$ Library, China West Normal University, Nanchong City, China
}

Corresponding author: X.H. Liu

E-mail: liuxiaohong0817@aliyun.com

Genet. Mol. Res. 13 (1): 276-282 (2014)

Received January 28, 2013

Accepted May 20, 2013

Published January 17, 2014

DOI http://dx.doi.org/10.4238/2014.January.17.12

\begin{abstract}
Aloe, an important folk herbal drug, includes abundant polysaccharides and secondary metabolites, which make it difficult to isolate high-quality DNA or RNA. In this paper, one and two improved methods were used to isolate the genomic DNA and RNA from the leaf of aloe, respectively. The obtained samples presented good quality and integrity; thus, they could be further used for many downstream molecular experiments. These reported protocols for DNA and RNA extraction offered a valuable reference for other related studies.
\end{abstract}

Key words: Aloe; Nucleic acids; Extraction; Purification 


\section{INTRODUCTION}

It is well known that high-quality DNA and RNA extraction is a critical factor in molecular biological procedures, such as polymerase chain reaction (PCR), cDNA library construction, and Northern blot hybridization. However, extraction of high-quality DNA and RNA from some plant tissues (e.g., fruit and seeds) is often difficult because some tissues contain high levels of polysaccharides, tannins, polyphenols, and some secondary metabolites (Benjamin et al., 1999; Luis and Jesús, 2008; Yan et al., 2009). Currently, several DNA and RNA extraction procedures have been developed to overcome the problem (Sassa, 2007; Ding et al., 2008), but only a few reports have been used in aloe (Zhao et al., 2008). Moreover, the use of some popular commercial kits is often limited for some special plant materials such as aloe (Yuan et al., 2005; Pandit et al., 2007; Sun et al., 2009).

Aloe (scientific name is Aloe spp), a genus belonging to the family Aloaceae (www. ipni.org), is a kind of perennial and evergreen plant. It originated in the dry region of Africa, but it is currently distributed throughout the world (Ma et al., 2010). Aloe is rich in many bioactive ingredients, and the products explored from it have wide applications in many fields such as medicine, health care, cosmetics, and food (Chang et al., 2007; Wang, 2009). According to previous reports, the studies on aloe were mainly focused on its medicinal components and pharmacological effects, while studies at the molecular level were rarely reported (Liu et al., 2011).

Therefore, the objectives of this research were to 1) develop simple and effective methods to isolate high-quality DNA and RNA from the leaves of aloe in an open-laboratory environment, and 2) obtain enough DNA and RNA to be used in downstream experiments.

\section{MATERIAL AND METHODS}

\section{Solutions and reagents}

Extraction buffer I consisted of $100 \mathrm{mM}$ Tris-Cl, $\mathrm{pH} 8.0,50 \mathrm{mM}$ ethylenediaminetetraacetic acid (EDTA), $500 \mathrm{mM} \mathrm{NaCl}$, and 2\% (v/v) 2-mercaptoethanol (2-ME) (added just prior to use). Extraction buffer II contained $2 \%$ cetyltrimethylammonium bromide (CTAB), $1.4 \mathrm{M} \mathrm{NaCl}, 100 \mathrm{mM}$ Tris-Cl, $\mathrm{pH}$ 8.0, 0.5 M EDTA, pH 8.0, and 2\% (v/v) 2-ME (added before using). Additional solutions or reagents included Trizol [Sangon Biotech (Shanghai), Co., Ltd., China], RNAiso Plus [Takara Biotech (Dalian), Co., Ltd., China], polyvinylpyrrolidone 40 (PVP 40), $2.5 \mathrm{M}$ potassium acetate (KAc), $\mathrm{pH}$ 5.2, isopropanol, 70\% ethanol, chloroform:isoamyl alcohol (24:1), RNase-free $\mathrm{ddH}_{2} \mathrm{O}$, and ethidium bromide. Partial solutions, reagents, and consumables that were used for RNA extraction needed to be treated with $0.1 \%$ diethyl pyrocarbonate (DEPC).

\section{Plant materials}

Six Aloe spp, including A. arborescens, A. varavia, A. vera, A. ferox, A. africana, and A. saponaria, were collected and conserved in our laboratory. DNA samples were isolated from the leaf tissue of the six species, and RNA samples were extracted from the leaf tissue of $A$. arborescens and A. varavia. All collected leaves were first frozen in liquid nitrogen and then stored at $-20^{\circ} \mathrm{C}$ before processing. 


\section{DNA extraction}

An improved CTAB method was used to isolate DNA from aloe based on the report by Doyle and Doyle (1987), and the basal procedures consisted of the following steps.

1) Approximately $1.0 \mathrm{~g}$ leaves and small amounts of PVP 40 powder $(0.1 \mathrm{~g}$ per $1.0 \mathrm{~g}$ leaves) were ground into fine powder in a liquid nitrogen-chilled mortar.

2) The powder was then immediately transferred to a $2-\mathrm{mL}$ centrifuge tube. Subsequently, $1 \mathrm{~mL}$ cold extraction buffer I was added to the tube, homogenized quickly by vortexing, and placed at room temperature (RT) for about $10 \mathrm{~min}$. Afterwards, the tube was centrifuged at $4^{\circ} \mathrm{C}$ and $8000 \mathrm{rpm}$ for $10 \mathrm{~min}$.

3) The supernatant was discarded, and the precipitate was suspended in $1 \mathrm{~mL}$ preheated extraction buffer II. The mixture was incubated at $65^{\circ} \mathrm{C}$ at least $1 \mathrm{~h}$ with gentle shaking occasionally. After incubation, the mixture was centrifuged at $4^{\circ} \mathrm{C}$ and $8000 \mathrm{rpm}$ for $10 \mathrm{~min}$.

4) The supernatant was carefully transferred to a new $2-\mathrm{mL}$ centrifuge tube, and then an equal volume of chloroform:isoamyl alcohol (24:1) was added to the tube and mixed gently by inversion for $1 \mathrm{~min}$. The tube was kept at RT for $10 \mathrm{~min}$ and centrifuged at $4{ }^{\circ} \mathrm{C}$ and 10,000 rpm for $10 \mathrm{~min}$.

5) The aqueous phase was carefully transferred to a fresh $2-\mathrm{mL}$ centrifuge tube, about one-tenth the volume of $2.5 \mathrm{M}$ KAc solution, $\mathrm{pH} 5.2$, was added, and the chloroform:isoamyl alcohol (24:1) treatment was repeated as stated above.

6) The upper aqueous phase was transferred to another new 2-mL tube and two-thirds the volume of ice-cold isopropanol was added. The tube was maintained at $-20^{\circ} \mathrm{C}$ for more than $30 \mathrm{~min}$ and centrifuged at $4^{\circ} \mathrm{C}$ and $12,000 \mathrm{rpm}$ for $10 \mathrm{~min}$.

7) The supernatant was removed, and the pellet containing DNA was washed once or twice with $70 \%$ ethanol and dried under the natural environment.

8) The final DNA precipitate was dissolved in $50 \mu \mathrm{L}$ sterilized double-distilled water.

\section{RNA extraction}

Two improved methods were used to extract RNA from two Aloe spp, including $A$. arborescens and $A$. varavia. The differences between the two methods were only the key reagents, one used Trizol and the other used RNAiso Plus. The two methods were named the Trizol method and the RNAiso method. Their procedures were as follows.

1) About $0.1 \mathrm{~g}$ aloe leaves was frozen in liquid nitrogen and ground into fine powder.

2) The fine powder was transferred to a $2-\mathrm{mL}$ centrifuge tube, mixed immediately with $1 \mathrm{~mL}$ Trizol (Trizol method) or RNAiso Plus (RNAiso method), and supplemented with $200 \mu \mathrm{L} 2-\mathrm{ME}$ and $200 \mu \mathrm{L} 2.5 \mathrm{M}$ KAc buffer, pH 5.2. After being mixed by vortexing, it was incubated at RT for $10 \mathrm{~min}$ and centrifuged at $4^{\circ} \mathrm{C}$ and $10,000 \mathrm{rpm}$ for $5 \mathrm{~min}$.

3) The aqueous phase was transferred to a new $2.0-\mathrm{mL}$ tube, and $300 \mu \mathrm{L} 2.5 \mathrm{M} \mathrm{KAc}$ buffer and an equal volume of chloroform:isoamyl alcohol (24:1) were added. Subsequently, the mixture was vortexed, incubated for $10 \mathrm{~min}$ at RT, and centrifuged at 10,000 rpm for $10 \mathrm{~min}$.

4) The supernatant was carefully transferred to another new tube, and the chloroform:isoamyl alcohol (24:1) treatment was repeated as stated above.

5) The upper aqueous phase was removed and two-thirds the volume of ice-cold isopropanol was added to the tube. The tube was kept at $-20^{\circ} \mathrm{C}$ for more than $30 \mathrm{~min}$ and centrifuged at $12,000 \mathrm{rpm}$ for $10 \mathrm{~min}$ at $4^{\circ} \mathrm{C}$. 
6) The supernatant was discarded, and the pellet was washed with $70 \%$ ethanol once or twice and then dried under the natural environment.

7) Finally, the obtained RNA precipitate was dissolved in 30-50 $\mu \mathrm{L}$ sterilized DEPCtreated water.

\section{Analysis of the quality and quantity of DNA and RNA samples}

The quantity and quality of the obtained DNA and RNA were determined by monitoring the $\mathrm{A}_{260} / \mathrm{A}_{280}$ absorbance ratio with the NanoDrop 2000 spectrophotometer. In addition, $5 \mu \mathrm{L}$ of each sample was used to evaluate the integrity and contamination status by $1 \%$ regular agarose gel electrophoresis in 1X Tris/borate/EDTA (TBE) buffer and was stained with EB.

\section{RESULTS}

\section{Identification of extracted DNA and RNA samples by spectrophotometry}

During DNA extraction, the final DNA pellet was white with no visible discoloration. However, the final RNA pellet could not be seen during the last phase of RNA extraction, which may be caused by few leaves used in the experiment.

The quality and purity of extracted DNA and RNA samples were assessed by spectrophotometry with $2 \mu \mathrm{L}$ of each sample. As a result, the $\mathrm{A}_{260} / \mathrm{A}_{280}$ absorbance ratios of DNA and RNA samples were near to 2.0 (Tables 1 and 2), indicating that the DNA and RNA samples that were isolated using these approaches were largely free of protein contamination.

Table 1. Testing results of the DNA samples from different Aloe spp materials by spectrophotometry.

\begin{tabular}{lcccc}
\hline Materials & $\mathrm{A}_{260}$ & $\mathrm{~A}_{280}$ & $\mathrm{~A}_{260} / \mathrm{A}_{280}$ & Concentration $(\mathrm{ng} / \mu \mathrm{L})$ \\
\hline A. arborescens & 2.005 & 0.994 & 2.02 & 100.3 \\
A. varavia & 2.577 & 1.206 & 2.14 & 128.9 \\
A. vera & 2.943 & 1.397 & 2.11 & 147.2 \\
A. ferox & 3.925 & 1.839 & 2.13 & 196.2 \\
A. africana & 2.154 & 1.010 & 2.13 & 107.7 \\
A. saponaria & 2.092 & 0.985 & 2.12 & 104.6 \\
\hline
\end{tabular}

Table 2. Testing results of the RNA samples extracted from Aloe arborescens and A. varavia materials by spectrophotometry.

\begin{tabular}{llcccr}
\hline Materials & Extraction methods & $\mathrm{A}_{260}$ & $\mathrm{~A}_{280}$ & $\mathrm{~A}_{260} / \mathrm{A}_{280}$ & Concentration $(\mathrm{ng} / \mu \mathrm{L})$ \\
\hline A. arborescens & Trizol method & 2.139 & 1.063 & 2.03 & 85.5 \\
\multirow{3}{*}{ varavia } & RNAiso method & 2.748 & 1.322 & 2.08 & 109.9 \\
& Trizol method & 2.122 & 1.138 & 1.86 & 84.9 \\
\hline
\end{tabular}

\section{Identification of isolated DNA and RNA samples by agarose gel electrophoresis}

The DNA results are displayed in Figure 1. The extracted DNA possessed good purity and was free from contamination by polysaccharides and polyphenols. Furthermore, no 
visible RNA bands existed on these corresponding lanes, which suggested that the RNA was completely eliminated.

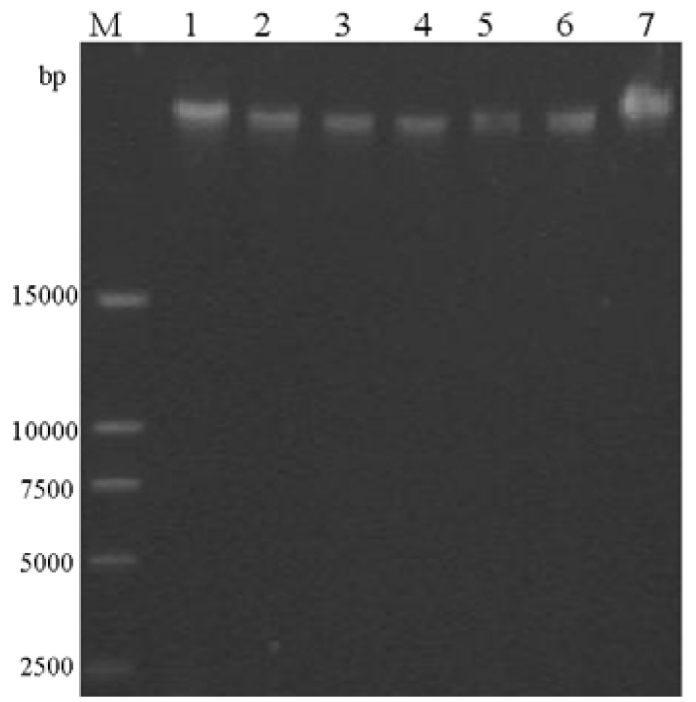

Figure 1. Genomic DNA extracted from six aloe species was identified by electrophoresis. Lanes 1-6=Aloe ferox, $A$. arborescens, $A$. varavia, A. vera, $A$. africana, and $A$. saponaria, respectively; lane $7=\lambda$ DNA; lane $M=\mathrm{DNA}$ marker.

The RNA results are shown in Figure 2. All of the RNA samples presented good integrity because their $28 \mathrm{~S}$ and $18 \mathrm{~S}$ electrophoresis bands were quite clear. Thus, these RNA samples could be used for related downstream experiments.

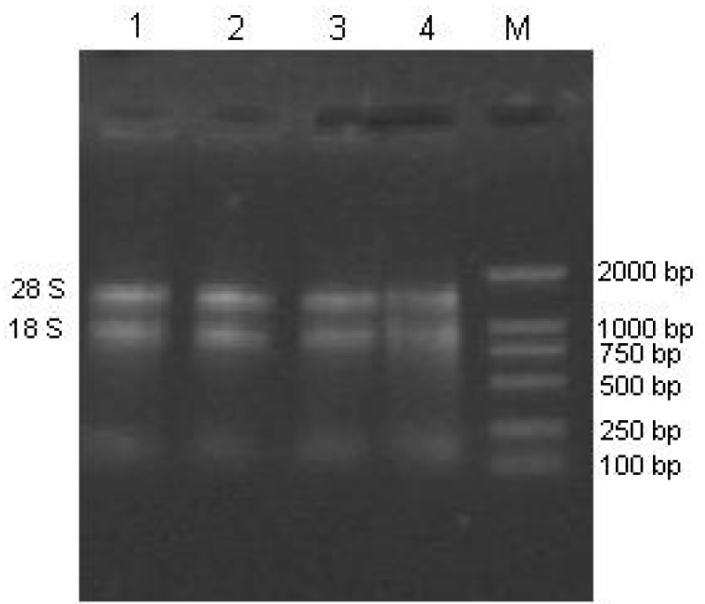

Figure 2. RNA from two aloe materials was analyzed by electrophoresis. Lanes 1-4 = Aloe arborescens (Trizol method), A. arborescens (RNAiso method), A. varavia (Trizol method), and A. varavia (RNAiso method), respectively; lane $M=$ ladder marker. 


\section{DISCUSSION}

Many DNA and RNA isolation methods have been developed, such as the improved CTAB method, sodium dodecyl sulfate (SDS) method, and a variety of commercial nucleic acid purification kits (Yang, 2006; Li et al., 2007). However, for special plants, the extraction methods are unsuitable because of the physiological and structural differences of the plant itself and the interference of secondary metabolites (Li et al., 2007; Hu et al., 2009). For instance, the polysaccharide contents are different in different plants, but their physiological and chemical characteristics are similar between different plants. Polysaccharides can be precipitated by ethanol or isopropanol. Once the carbohydrates and the DNA or RNA were coprecipitated during sample preparation, a large pellet formed at the bottom of the centrifugation tube where the nucleic acid was trapped and not easily dissolved (Chang et al., 1993). Therefore, polysaccharides must be removed before the precipitation. To resolve this problem, a high concentration salt solution (such as $5 \mathrm{M} \mathrm{NaCl}$ and $2.5 \mathrm{M} \mathrm{NaAc}$ ) and a low concentration of ethanol (10-30\%) are often used (Chang et al., 1993; Pandit et al., 2007; Yang et al., 2009). At the same time, polyphenols and some secondary metabolites are easily oxidized into reddish-brown substances, which can combine irreversibly with nucleic acid in the process of extraction. To eliminate them, the addition of some antioxidants such as 2-ME, dithiothreitol (DTT) and chelators (i.e., PVP 40) are necessary because of their special effects (Fang, 1999).

A great number of studies revealed that aloe contained abundant polysaccharides and secondary metabolites (Bao and Jia, 2009). Khanuja et al. (1999) observed that these secondary compounds could hamper DNA isolation and further molecular analysis. Therefore, these compounds must be eliminated during nucleic acid isolation.

In this study, PVP 40 and 2-ME were added while pestling the leaf tissues and using extraction buffer, respectively. In the following step of DNA and RNA extraction, a high-concentration KAc solution (2.5 M, pH 5.2) was added to remove polysaccharides effectively. The KAc was added during RNA extraction because it could remove polysaccharides and maintain a stable $\mathrm{pH}$ value. Yuan et al. (2005) found that the RNA samples were contaminated by DNA when the $\mathrm{pH}$ value of the extraction buffer was 6.0 , and a similar phenomenon was also observed in our experiment (data not shown). According to the quality and quantity results, the obtained DNA and RNA samples were not contaminated by organic matters including polyphenols, polysaccharides and protein; this suggested that they were completely removed.

In conclusion, we have successfully isolated high-quality DNA and RNA from aloe by improved methods. The extracted DNA and RNA samples could be further used for downstream experiments. More significantly, the reported protocols here could be an important reference for related studies.

\section{ACKNOWLEDGMENTS}

Research supported by the Scientific Research Fund of Sichuan Provincial Education Department (\#13ZA0012) and the Start Fund of China West Normal University (\#07B031), Sichuan Province, P.R. China.

\section{REFERENCES}

Bao RH and Jia HQ (2009). Active components and immune function of aloe. Fujian Agr. Sci. Technol. 5: 66-69. 
Benjamin K, Stacy R and David AD (1999). DNA isolation method for high polysaccharide Lesquerella species. Ind. Crops Prod. 9: 111-114.

Chang S, Puryear J and Cairiney J (1993). A simple and efficient method for isolating RNA from pine trees. Plant Mol. Biol. Rep. 11: 113-116.

Chang XL, Feng YM, Cong LH and Tian KM (2007). Review update on bioactive functions of aloe. Food Sci. Technol. 5: 10-13.

Ding LW, Sun QY, Wang ZY, Sun YB, et al. (2008). Using silica particles to isolate total RNA from plant tissues recalcitrant to extraction in guanidine thiocyanate. Anal. Biochem. 374: 426-428.

Doyle JJ and Doyle JL (1987). A rapid DNA isolation procedure for small quantities of fresh leaf tissue. Phytochem. Bull. 9: $11-15$

Fang ZG (1999). The active ingredients and their effects in Aloe. Chin. J. Trop. Agr. 1: 59-62.

Hu YP, Xie XL, Wang L and Yang J (2009). An effective and low-cost method for DNA extraction from herbal drugs of Rheum tanguticum (Polygonaceae). Afr. J. Biotechnol. 8: 2691-2694.

Khanuja SS, Shasany A, Darokar MP and Kumar S (1999). Rapid isolation of DNA from dry and fresh samples of plants producing large amounts of secondary metabolites and essential oils. Plant Mol. Biol. Rep. 17: 1-74.

Li JT, Yang J, Chen DC, Zhang XL, et al. (2007). An optimized mini-preparation method to obtain high-quality genomic DNA from mature leaves of sunflower. Genet. Mol. Res. 6: 1064-1071.

Liu XH, Li J, Zhang YS and Li LH (2011). Biological research advancement of aloe. J. Med. Plant Res. 5: 1046-1050.

Luis SO and Jesús VC (2008). DNA-free RNA isolation protocols for Arabidopsis thaliana, including seeds and siliques. BMC Res. Notes 1: 1-7.

Ma YP, Xu CX and Liu YL (2010). Specific structure and bioactive components in leaf blade of aloe and the adaptation to stresses. Chin. J. Trop. Crops 31: 676-688.

Pandit SS, Mitra SS, Giri AP and Gupta VS (2007). A quick method for isolating RNA from raw and ripe fleshy fruits as well as for co-isolating DNA and RNA from polysaccharide and polyphenol-rich leaf tissues. J. Plant Biol. 50: 60-64.

Sassa H (2007). A technique to isolate DNA from woody and herbaceous plants by using a silica-based plasmid extraction column. Anal. Biochem. 363: 166-167.

Sun DQ, Guo QG, Hu YL and Xie JH (2009). Extraction of total RNA from banana with improved Trizol method. Guangdong Agr. Sci. 5: 162-164.

Wang LC (2009). Research advance on the main chemical components of aloe leaf and their efficacies. Anim. Husbandry Feed Sci. 30: 25-26.

Yan EW, Liu H and Wang YC (2009). A method for isolation of total RNA from Schisandra chinesis. Forest By-Product Speciality 4: 17-18.

Yang PY (2006). Plant Molecular Biology Technology Application Manual. Chemical Industry Press, Beijing, 295-294.

Yang ZJ, Qin SG and Zhang J (2009). Characteristics of several extraction methods on total RNA in plant tissues and strategies to problems. J. Anhui Agr. Sci. 37: 8341-8342.

Yuan MZ, Wen R, Liu JS and Jie YS (2005). Isolation of total RNA from different plant species. Mol. Plant Breed. 3: 285-292.

Zhao CX, Ma LH and Yang TW (2008). Extraction of total RNA in Aloe vera L. var. chinensis leaf with improved CTAB method. J. Anhui Agr. Sci. 36: 6671-6672. 